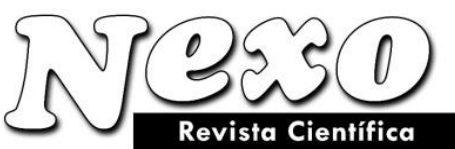

Vol. 34, No. 02, pp. 886-905/Junio 2021
ISSN-E 1995-9516

Universidad Nacional de Ingeniería COPYRIGHT @ (UNI). TODOS LOS DERECHOS RESERVADOS http://revistas.uni.edu.ni/index.php/Nexo https://doi.org/10.5377/nexo.v34i02.11613

\title{
Mathematical modeling of islanded microgrid with static and dynamic loads
}

\section{Modelado matemático de microred isla con cargas estáticas y dinámicas}

\author{
Hamed Ahmadi*, Qobad Shafiee, Hassan Bevrani \\ Smart/Micro Grids Research Center. University of Kurdistan, Sanandaj, Iran \\ *h.ahmadi@eng.uok.ac.ir
}

(recibido/received: 25-enero-2021; aceptado/accepted: 29-abril-2021)

\begin{abstract}
Increasing the penetration level of distributed generation units as well as power electronic devices adds more complexity and variability to the dynamic behavior of the microgrids. For such systems, studying the transient modelling and stability is essential. One of the major disadvantages of most studies on microgrid modelling is their excessive attention to the steady state period and the lack of attention to microgrid performance during the transient period. In most of the research works, the behavior of different microgrid loads has not been studied. One of the mechanisms of power systems stability studies is the application of state space modelling. These studies include the development of state space models of various components of the power system and then linearizing them around an equilibrium point. In this paper, a comprehensive method for modelling of islanded microgrid with dynamic and static loads is presented. The basic step of the proposed method is transformation to a dq0-based model. In order to find a complete and accurate model of islanded inverter-based microgrid, the sub-modules of generation, network and load must be modelled in local dq reference and then transferred to a common reference. The simulation results show the effectiveness of the proposed modelling approach for transient stability studies.
\end{abstract}

Keywords: Distributed generation, Dynamic modelling, Microgrid, State space, Transient state.

\section{RESUMEN}

Aumentar el nivel de penetración de las unidades de generación distribuida y de los dispositivos electrónicos de potencia añade más complejidad y variabilidad al comportamiento dinámico de las microrredes. Para tales sistemas, el estudio del modelado y la estabilidad transitorios es esencial. Una de las principales desventajas de la mayoría de los estudios sobre modelado de microrredes es su excesiva atención al período de estado estable y la falta de atención al rendimiento de la microrred durante el período transitorio. En la mayoría de los trabajos de investigación no se ha estudiado el comportamiento de diferentes cargas de microrredes. Uno de los mecanismos de los estudios de estabilidad de sistemas de potencia es la aplicación del modelado del espacio de estados. Estos estudios incluyen el desarrollo de modelos espaciales de estados de varios componentes del sistema de energía y luego linealizarlos alrededor de un punto de equilibrio. En este artículo, se presenta un método integral para el modelado de microrredes en islas con cargas dinámicas y estáticas. El paso básico del método propuesto es la transformación a un modelo basado en dq0. Para encontrar un modelo completo y preciso de microrred basada en inversor en isla, los submódulos de generación, red y carga deben modelarse en la referencia dq local y luego transferirse a una referencia 
común. Los resultados de la simulación muestran la efectividad del enfoque de modelado propuesto para estudios de estabilidad transitoria.

Palabras claves: Generación distribuida, Modelado dinámico, Microrred, Espacio de estados, Estado transitorio.

\section{INTRODUCTION}

Today's modern world needs high quality electricity and reliability desperately. The importance of energy, greenhouse gas emissions, environmental pollution, non-renewability of fossil fuels, degradation of transmission and distribution network equipment and the need for large investments to develop and modernize their basic infrastructure on the one hand and on the other hand, the need for high-quality electricity and reliability has made the use of renewable energy units as a source of electricity in many developed countries. One of the most suitable options for power supply is distributed generation units which are one of the most important sources of electricity supply today. Active distribution networks or microgrids are referred to as low voltage networks, including distributed generation units such as wind turbines, solar power plants, micro turbines, energy storage devices such as batteries, flywheels, super capacitors, sensitive loads and interruptible loads that are connected to an upstream medium voltage grid by a transformer. Due to the presence of distributed generation units at the distribution level, the nature of the microgrids is very different from the conventional grid. Compared to traditional power systems, different types of small resources are used in microgrids. As a result of the small number of multiple sources, the dynamic model of the microgrid will be more complex (Bevrani, François, \& Ise, 2017; Du, Lu, Wang, \& Lukic, 2018; Pérez-Ibacache, Silva, \& Yazdani, 2018; Sarkar, Badal, \& Das, 2018).

In modelling, attention must be paid to the size and accuracy of the model and its validity. So far, many studies have been done on the modelling and control of microgrids (Serra, De Angelo, \& Forchetti, 2014). In (Serra, et al., 2014), a new non-linear control strategy is proposed to connect the renewable energy sources to the network. In (Pérez, Ortega, \& Espinoza, 2004), a linear PI controller is designed to stabilize the nonlinear systems. In (Smith \& McCann), the authors propose a new control method to increase the stability of a two-level converter of renewable energies in order to improve the transient state of the connected mode to the islanding mode. Reference (Jafari, Mahmoudi, Fatehi, Naderi, \& Kaya) describes a new strategy for optimal power sharing control of a microgrid. In (Belvedere et al., 2012), a preliminary control strategy for a microcontroller comprising a variety of energy sources is proposed to improve transient behaviour in connected and isolated states. In (Nguyen, Nguyen, Yoo, \& Kim, 2018), a new control strategy based on the theory of virtual synchronous generator is proposed to improve the transient response of power converters in the presence of a large disturbance in the islanding mode. In (Wang, Guerrero, Blaabjerg, \& Chen, 2012), an overview of the microcontroller structure and possible structural options and different methods of controlling the distributed generations is provided. References (Ortega \& Milano, 2015) and (Ortega \& Milano, 2016) present a general model of energy storage system for voltage and angle stability analysis. The proposed method allows one to model current of energy storage technologies through a set of differential algebraic equations. In (Zhu \& Tomsovic, 2002), a simple dynamic model for micro turbines and fuel cells is presented. In (Wai \& Wang, 2008), the description of a grid connected photovoltaic system is performed with greater flexibility in the presence of the inverter. The exact dynamical equations for the power system and wind energy conversion systems are presented in (Stavrakakis \& Kariniotakis, 1995).

In (Hatziargyriou et al.), the model description of various types of energy generators in microgrids, especially micro turbines, fuel cells, photovoltaic and wind turbines has been performed. In (Kanellos, Tsouchnikas, \& Hatziargyriou), the steady state and transient state studies of a microgrid is performed. Also, the model of wind energy and photovoltaic conversion system along with modelling of power electronic interfaces and existing control strategies are presented. In (Ou \& Hong, 2014), new methods for evaluating the stability of a microgrid performance in both connected and islanding modes are presented. In addition, 
linear and non-linear models of microgrid in different operating modes, with optimized LC filter design and optimization of control parameters and power sharing coefficients of independent performance mode have also been performed.

The dynamic model of distributed generation as part of the power system is provided in (Ishchenko, 2008). Linear and nonlinear models give a good description of the system. A variety of order reduction methods are presented to simplify the models. The performance of the distribution network in the presence of distributed generations and in spite of small disturbance is investigated. In (Alam, Moreira, Islam, \& Mehedi), the development of appropriate simulation models and methods for investigating the dynamics of microgrids in transient stability has been performed. This is to investigate the interaction of the microgrid in connected and islanding operation modes. All the components of the microgrids are modelled with sources, loads, lines and power electronic interfaces. The frequency and stability characteristics of a microgrid are discussed in (Soni, Doolla, \& Chandorkar, 2017). A method for analysing the inertia coefficient is proposed based on the theory that near-frequency sources experience the same frequency. In (Hassan, 2018), a new method for tracking the reference voltage of the grid to synchronize active loads is

proposed. An independent microgrid model and design and the effect of active loads on the stability of the independent microgrid are also discussed. In (Ferraro, Crisostomi, Shorten, \& Milano, 2018), a stochastic control strategy is presented to manage the power distribution of the connected microgrids.

The rest of this paper is organized as follows. In Section2, a generalized model for islanded inverter-based microgrids with static and dynamic loads has been developed. Section 3 presents the validation of the proposed modelling approach through time-domain simulations. Conclusions are drawn in Section 4.

\section{GENERALIZED MODELLING OF ISLANDED INVERTER-BASED MICROGRIDS WITH STATIC AND DYNAMIC LOADS}

A full non-linear dynamic model of the islanded inverter-based microgrid is developed using the synchronous rotating reference. The model consists of three sub-modules: generation sub-module, network sub-module and load sub-module.

\subsection{Generation sub-module}

The generation sub-module contains the modelling of islanded inverter-based microgrid units and their control structure as shown in Figure 1.

The inverter-based distributed generation controller can be divided into three separate parts. The first part is the outer loop power control which adjusts the amplitude and frequency of the main components of the inverter output voltage according to the drop technique (Rocabert, Luna, Blaabjerg, \& Rodriguez, 2012). The second and third parts are current and voltage controllers which are designed to prevent high frequency disturbances and provide the damping required for the output filter. 


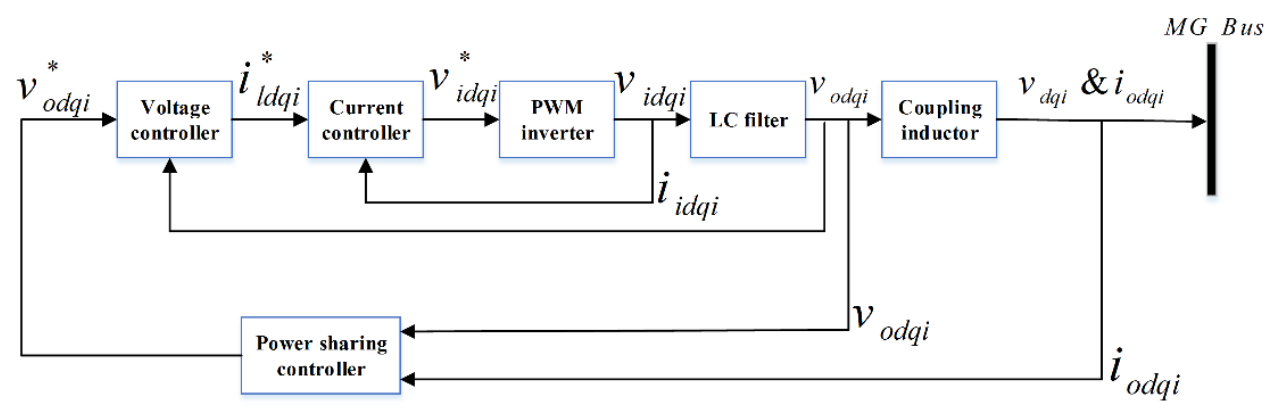

Figure 1. The control structure of islanded inverter-based microgrid units.

Some system state variables are considered as virtual control inputs and appropriate reference values are chosen so that the outputs of the system will follow their own reference values.

The instantaneous power components are passed through a low-pass filter. The low-pass filter cut-off frequency determined through the coordination between the bandwidth of the control loop and the time difference between the control responses. As a result, filter and drop control coefficients have largely effects on dynamics response and stability of the inverter (Pogaku, Prodanovic, \& Green, 2007). Proper damping and oscillation of the inverter system modes lead to instability and high circulation current that can cause overload and damage to DG units. The reference frequency and voltage of $i$-th islanded inverter-based distributed generation are given by (1) to (2), respectively.

$$
\begin{gathered}
\omega_{i-d r}^{*}=\omega_{n}-m_{p i} P_{i} \\
v_{o d i-d r}^{*}=V_{n}-n_{Q i} Q_{i}, \quad v_{o q i-d r}^{*}=0
\end{gathered}
$$

In above equations, $\omega_{n}$ and $V_{n}$ are the nominal set points of frequency and d-axis output voltage, respectively; $\mathrm{m}_{\mathrm{Pi}}$ and $\mathrm{n}_{\mathrm{Qi}}$ represent static active and reactive power droop gains, respectively; and $\mathrm{P}_{\mathrm{i}}$ and $\mathrm{Q}_{\mathrm{i}}$ are the average active and reactive powers of the $\mathrm{i}$-th islanded-inverter based distributed generation, respectively. The active and reactive powers utilized in (1) and (2) are given in (3) and (4), respectively.

$$
\begin{aligned}
& \dot{P}_{i}=-P_{i} \omega_{c}+\omega_{c} \times 1.5\left(v_{o d i} i_{o d i}+v_{o q i} i_{o q i}\right) \\
& \dot{Q}_{i}=-Q_{i} \omega_{c}+\omega_{c} \times 1.5\left(v_{o q i} i_{o d i}-v_{o d i} i_{o q i}\right)
\end{aligned}
$$

where $v_{\text {odi }}, v_{\text {oqi }}, i_{\text {odi }}$ and $i_{\text {oqi }}$ are the output voltages and currents of the $i$-th islanded-inverter distributed generation in DQ reference frame, respectively and $\omega_{c}$ is cut-off frequency of the low-pass filter. Inner loop voltage and current controllers are designed to reject high-frequency disturbances and provide sufficient damping to the output LC filter. Block diagram of voltage and current controller. Voltage controller performs the task of controlling the output voltage at a suitable quality using a PI controller. Also, the current controller is accomplished with a PI controller. The current controller has been adopted to prevent overcurrent. The dynamical equations of voltage and current controllers are given in (5) - (12), respectively. 


$$
\begin{aligned}
& v_{o d_{-} K_{i v} i}=K_{i v}\left(v_{o d i}^{*}-v_{o d i}\right) \\
& v_{o q_{-} K_{i v} i}=K_{i v}\left(v_{o q i}^{*}-v_{o q i}\right) \\
& i_{l d i}^{*}=K_{p v}\left(v_{o d i}^{*}-v_{o d i}\right)+v_{o d_{-} K_{i v} i}-\omega_{n} C_{f} v_{o q i}+F i_{o d i} \\
& i_{l q i}^{*}=K_{p v}\left(v_{o q i}^{*}-v_{o q i}\right)+v_{o q_{-} K_{i v} i}+\omega_{n} C_{f} v_{o d i}+F i_{o q i} \\
& i_{l d_{-} K_{i c} i}=K_{i c}\left(i_{l d i}^{*}-i_{l d i}\right) \\
& i_{l q_{-} K_{i c} i}=K_{i c}\left(i_{l q i}^{*}-i_{l q i}\right) \\
& v_{i d i}^{*}=K_{p c}\left(i_{l d i}^{*}-i_{l d i}\right)+i_{l d_{-} K_{i c} i}-\omega_{n} L_{f} i_{l q i} \\
& v_{i q i}^{*}=K_{p c}\left(i_{l q i}^{*}-i_{l q i}\right)+i_{l q_{-} K_{i c} i}+\omega_{n} L_{f} i_{l d i}
\end{aligned}
$$

Where $\left(\mathrm{v}_{\text {odi }}, \mathrm{v}_{\text {oqi }}\right)$ and $\left(\mathrm{i}_{\text {odi }}, \mathrm{i}_{\text {oqi }}\right)$ are voltage and current of $\mathrm{i}$-th islanded inverter-based distributed generation units for $\mathrm{d}$ and $\mathrm{q}$ axis; $\left(\mathrm{v}_{\text {odi }}^{*}, \mathrm{v}_{\text {oqi }}{ }^{*}\right)$ and $\left(\mathrm{i}_{\text {odi }}{ }^{*}, \mathrm{i}_{\text {oqi }}{ }^{*}\right)$ are reference values of voltage and current of $\mathrm{i}$-th islanded inverter-based distributed generation units for $\mathrm{d}$ and $\mathrm{q}$ axis. $\omega_{n}$ is nominal frequency; $\mathrm{C}_{\mathrm{f}}$ and $\mathrm{L}_{\mathrm{f}}$ is capacitor and inductor of filter. Also, $\mathrm{K}_{\mathrm{pv}}, \mathrm{K}_{\mathrm{iv}}, \mathrm{K}_{\mathrm{pc}}$ and $\mathrm{K}_{\mathrm{ic}}$ are standard proportional and integral gains, and $\mathrm{F}$ is the feedforward gain. The voltage and current dynamics for the output LC filter and coupling inductance are given in (13) - (18).

$$
\begin{gathered}
i_{o d i}^{\bullet}=\frac{1}{L_{c}}\left(v_{o d i}-v_{b d i}-r_{c} i_{o d i}\right)+\omega i_{o q i} \\
i_{o q i}^{\bullet}=\frac{1}{L_{c}}\left(v_{o q i}-v_{b q i}-r_{c} i_{o q i}\right)+\omega i_{o d i} \\
i_{l d i}^{\bullet}=\frac{1}{L_{f}}\left(v_{i d i}-v_{o d i}-r_{f} i_{l d i}\right)+\omega i_{l q i} \\
i_{l q i}^{\bullet}=\frac{1}{L_{f}}\left(v_{i q i}-v_{o q i}-r_{f} i_{l q i}\right)-\omega \dot{i}_{l d i} \\
v_{o d i}^{\bullet}=\frac{1}{C_{f}}\left(i_{l d i}-i_{o d i}\right)+\omega v_{o q i}+R_{d}\left(\dot{i_{l d i}}-\dot{i_{o d i}}\right) \\
v_{o q i}^{\bullet}=\frac{1}{C_{f}}\left(i_{l q i}-i_{o q i}\right)-\omega v_{o d i}+R_{d}\left(\dot{i_{l q i}}-\dot{i_{o q i}}\right)
\end{gathered}
$$

Where $r_{f}$ and $r_{c}$ are the parasitic resistances of the inductors, $L_{f}$ and $C_{f}$, respectively. The resistance $R_{d}$ is a damping resistor, which is connected in series with the filter capacitor $\mathrm{C}_{\mathrm{f}}$. 


\subsection{Network sub-module}

Interference of microgrid and inverter-based distributed generations is performed with a voltage source inverter which have a small time constant. Due to the small time constant, network dynamics will have a considerable impact on the stability of the microgrid system. Dynamic equations of $\mathrm{i}$-th line between $\mathrm{j}$-th and k-th node are given by (19) and (20), as shown on Figure 2.

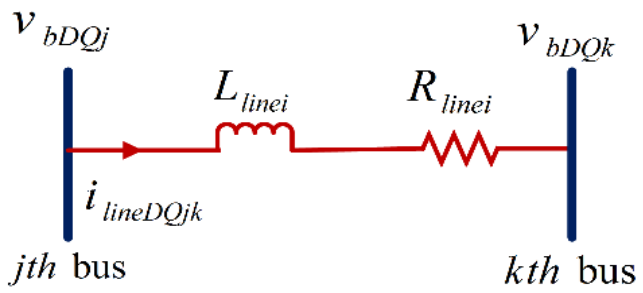

Figure 2. The configuration of RL line in network.

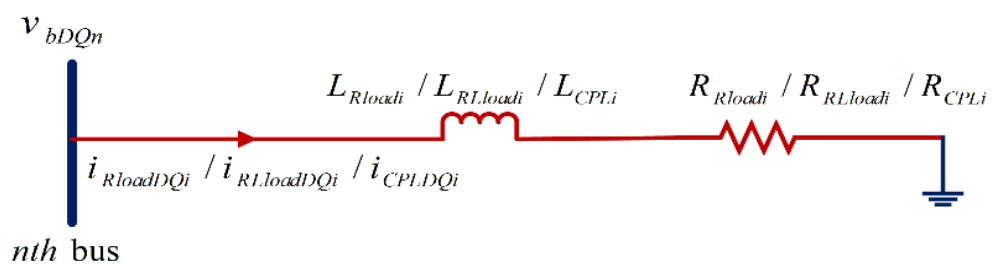

Figure 3. The configuration of passive load including (R), (RL) and (CPL) loads.

$$
\begin{aligned}
& \dot{i_{\text {lineDi }}}=-\frac{-R_{\text {linei }}}{L_{\text {linei }}} i_{\text {lineDi }}+\frac{1}{L_{\text {linei }}}\left(v_{b D j}-v_{b D k}\right)+\omega_{j} i_{\text {line } Q i} \\
& \dot{i_{\text {line } Q i}}=\frac{-R_{\text {linei }}}{L_{\text {linei }}} i_{\text {line } Q i}+\frac{1}{L_{\text {linei }}}\left(v_{b Q j}-v_{b Q k}\right)-\omega_{j} i_{\text {lineDi } i}
\end{aligned}
$$

\subsection{Load sub-module}

In this study, a combination of static and dynamic loads is considered. Static loads including resistive (R) load, inductive (RL) load and constant power load (CPL) and the dynamic load is induction motor that all connected to the islanded-inverter microgrid. The model for each of these loads is given below. The loads can be also classified into passive and active loads, which resistive (R), inductive (RL) and constant power (CPL) are passive.

\subsubsection{Passive load}

The dynamical equations of $\mathrm{i}$-th passive load connected at $\mathrm{n}$-th bus, as shown in Figure 3, in common dq reference frame is given in (21) and (22) (Bottrell, Prodanovic, \& Green, 2013): 


$$
\begin{aligned}
& \dot{i_{P L D i}}=\frac{-R_{P L i}}{L_{P L i}} i_{P L D i}+\frac{1}{L_{P L i}} v_{b D n N}+\omega i_{P L Q i} \\
& \dot{i_{P L Q i}}=\frac{-R_{P L i}}{L_{P L i}} i_{P L Q i}+\frac{1}{L_{P L i}} v_{b Q n N}-\omega i_{P L D i}
\end{aligned}
$$

where subscript PL will be replaced by $\mathrm{R}, \mathrm{RL}$ and CPL for passive loads. $\mathrm{R}_{\mathrm{PLi}}$ and $\mathrm{L}_{\mathrm{PLi}}$ of CPL loads are calculated as follow:

$$
\begin{aligned}
& R_{C P L}=-r_{C P L} \cos \alpha \\
& X_{C P L}=-r_{C P L} \sin \alpha
\end{aligned}
$$

Where $\alpha$ is the delay angle of a controlled rectifier.

\subsubsection{Active load}

One of the most important active loads is rectifier interfaced active load. The complete model of $i$-th RIAL in common DQ reference frame, is given in (25) to (37). The power and control structure of this load is shown in Figure 4, which The control section contains the outer DC voltage controller and inner AC current controller. It is noteworthy that this control structure is based on two equations (26) and (29).

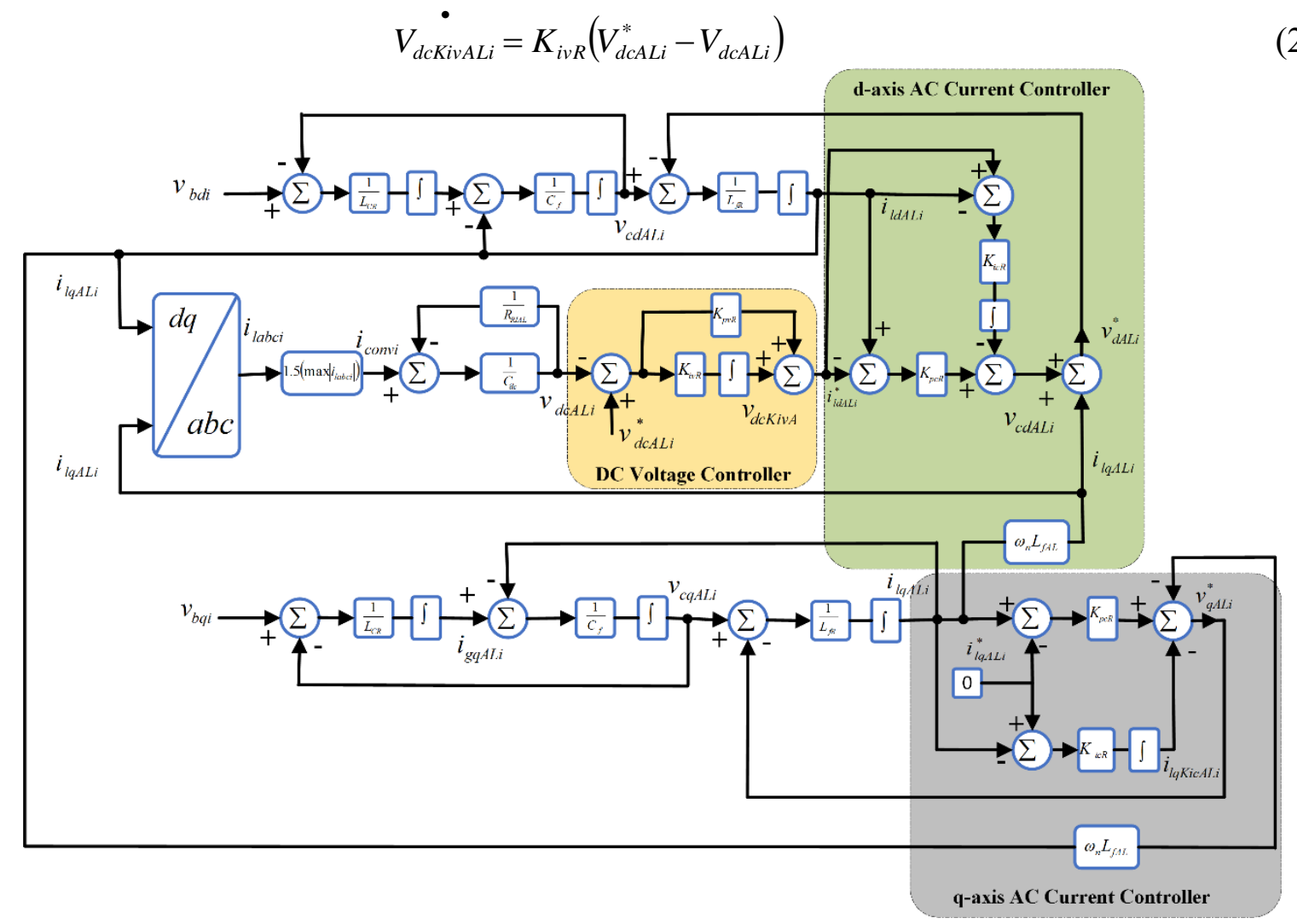

Figure 4. The outer DC voltage and inner AC current controllers of rectifier interfaced active load.

$$
i_{l d A L i}^{*}=K_{p v R}\left(V_{d c A L i}^{*}-V_{d c A L i}\right)+V_{d c K i v A L i}, i_{l q A L i}^{*}=0
$$




$$
\begin{aligned}
& i_{l d K i c A L i}^{\bullet}=K_{i c R}\left(K_{p v R}\left(V_{d c A L i}^{*}-V_{d c A L i}\right)+V_{d c K i v A L i}-i_{l d A L i}\right) \\
& i_{l q K i c A L i}^{\bullet}=K_{i c R}\left(i_{l q A L i}^{*}-i_{l q A L i}\right) \\
& V_{d A L i}^{*}=-K_{p c R}\left(K_{p v R}\left(V_{d c A L i}^{*}-V_{d c A L i}\right)+V_{d c K i v A L i}-i_{l d A L i}\right)-i_{l d K i c A L i}+\omega_{n} L_{f R} i_{l q A L i} \\
& V_{q A L i}^{*}=-K_{p c R}\left(i_{l q A L i}^{*}-i_{l q A L i}\right)-i_{l q K i c A L i}-\omega_{n} L_{f R} i_{l d A L i} \\
& \dot{i_{l d A L i}}=\frac{\left(V_{c d A L i}-V_{d A L i}^{*}\right)}{L_{f R}} \\
& i_{l q A L i}=\frac{\left(V_{c q A L i}-V_{q A L i}^{*}\right)}{L_{f R}} \\
& \dot{V}_{c d A L i}=\left(\frac{1}{C_{f}}\right)\left(i_{g d A L i}-i_{l d A L i}\right) \\
& \dot{V}_{c q A L i}=\left(\frac{1}{C_{f}}\right)\left(i_{g q A L i}-i_{l q A L i}\right) \\
& \dot{i}_{g d A L i}=\frac{\left(V_{b d i}-V_{c d A L i}\right)}{L_{c R}} \\
& \dot{i}_{g q A L i}=\frac{\left(V_{b q i}-V_{c q A L i}\right)}{L_{c R}} \\
& \dot{V}_{d c i}=\left(\frac{1}{C_{d c}}\right)\left(1.5\left(\max \left|i_{\text {labci }}\right|\right)-\frac{V_{d c A L i}}{R_{\text {load }}}\right)
\end{aligned}
$$

The outer DC voltage controller controls the DC voltage across the capacitor of DC link, and inner AC current controller controls the current through the inductor load. These controllers are controlled by using a standard PI controller. The DC voltage controller determines the reference input to the AC current controller, while the AC current controller controls the current through the inductor $\mathrm{L}_{\mathrm{fAL}}$. Furthermore, the $\mathrm{AC}$ current controller uses feed-forward terms to decouple the measured dq-axis inductor currents, $\mathrm{i}_{\mathrm{ldqALi}}$ (Ferraro, et al., 2018).

\subsubsection{Dynamic load}

The dynamic equations of $\mathrm{i}$-th microgrid-connected induction motor including the stator and rotor current and voltage in dq axis as well as the motor load torque are given below.

$$
\dot{i_{D s i}}=\left(\frac{1}{\left(L_{s i i}-\left(\frac{L_{m i}^{2}}{L_{r i i}}\right)\right)}\right)\left(V_{D s i}-\left(r_{s i} i_{D s i}-\omega_{i} L_{s s i} i_{Q s i}-\omega_{i} L_{m i} i_{Q r i}+\left(\frac{L_{m i}}{L_{r r i}}\right)\left(V_{D r i}-\left(r_{r i} i_{D r i}-s_{i} \omega_{i} L_{r i i} i_{Q r i}-s_{i} \omega_{i} L_{m i i} i_{Q s i}\right)\right)\right)\right)
$$




$$
\begin{gathered}
\dot{i_{Q s i}}=\left(\frac{1}{\left(L_{s i i}-\left(\frac{L_{m i}^{2}}{L_{r i i}}\right)\right)}\right)\left(V_{Q s i}-\left(r_{s i} i_{Q s i}+\omega_{i} L_{s s i} i_{D s i}+\omega_{i} L_{m i} i_{D r i}+\left(\frac{L_{m i}}{L_{r r i}}\right)\left(V_{Q r i}-\left(r_{s i i} i_{Q r i}+s_{i} \omega_{i} L_{r r i} i_{D r i}+s_{i} \omega_{i} L_{m i i} i_{D s i}\right)\right)\right)\right) \\
\dot{i_{D r i}}=-\left(\frac{L_{m i}}{L_{r r i}}\right) \dot{i_{D s i}}+\left(\frac{1}{L_{r r i}}\right)\left(V_{D r i}-\left(r_{r i} i_{D r i}-s_{i} \omega_{i} L_{r r i} i_{Q r i}-s_{i} \omega_{i} L_{m i} i_{Q s i}\right)\right) \\
\dot{i_{Q r i}}=-\left(\frac{L_{m i}}{L_{r r i}}\right) \dot{Q_{Q s i}}+\left(\frac{1}{L_{r r i}}\right)\left(V_{Q r i}-\left(r_{s i} i_{Q r i}+s_{i} \omega_{i} L_{r r i} i_{D r i}+s_{i} \omega_{i} L_{m i} i_{D s i}\right)\right) \\
T_{e i}=\left(\frac{3}{2}\right)\left(\frac{P_{i}}{2}\right) L_{m i}\left(i_{Q s i} i_{D r i}-i_{D s i} i_{Q r i}\right) \\
\dot{s_{i}}=-\frac{T_{e i}-T_{L i}}{J_{i} \omega_{i}}
\end{gathered}
$$

In equations (38)-(41), $\left(\mathrm{r}_{\mathrm{si}}, \mathrm{L}_{\mathrm{ssi}}\right)$ and $\left(\mathrm{r}_{\mathrm{ri}}, \mathrm{L}_{\mathrm{rri}}\right)$ are resistance and self-inductance of stator and rotor, respectively. In these equations, $\mathrm{L}_{\mathrm{mi}}, \mathrm{s}_{\mathrm{i}}$ and $\omega_{\mathrm{i}}$ are the linkage inductance, rotor slip, and the stator supply angular frequency, respectively. In (42) and (43), $\mathrm{P}_{\mathrm{i}}, \mathrm{T}_{\mathrm{Li}}$ and $\mathrm{J}_{\mathrm{i}}$ are the number of poles, load torque and combined motor and load inertia, respectively. In all the parameters of these equations, subscripts $\mathrm{i}$ represents the $\mathrm{i}$-th induction motor connected to the microgrid as the dynamic load.

\section{RESULTS AND DISCUSSION}

\subsection{Values of parameters}

In order to validate the proposed modelling mechanism for microgrid transient stability studies, the structure of Figure 5 is implemented in MATLAB environment where the operation frequency is $60 \mathrm{~Hz}$ and voltage is $230 \mathrm{~V}$. Each islanded inverter-based distributed generation provided by a distributed that may be a photovoltaic, a micro turbine, a fuel cell generator, etc. another components of islanded inverter-based distributed generation are voltage source inverter and a local controller that composed of power-sharing, voltage, and current controllers. In this simulation, bus 1 behaves as point of common coupling that to the main utility grid with an isolation switch and a $0.415 / 11 \mathrm{kV}$ step-up transformer. The parameters of islanded inverter-based distributed generation units ratings, static/active and reactive power droop gains, Lines, induction motor load, CPL, RIAL and R load are shown in Tables 1-3. 


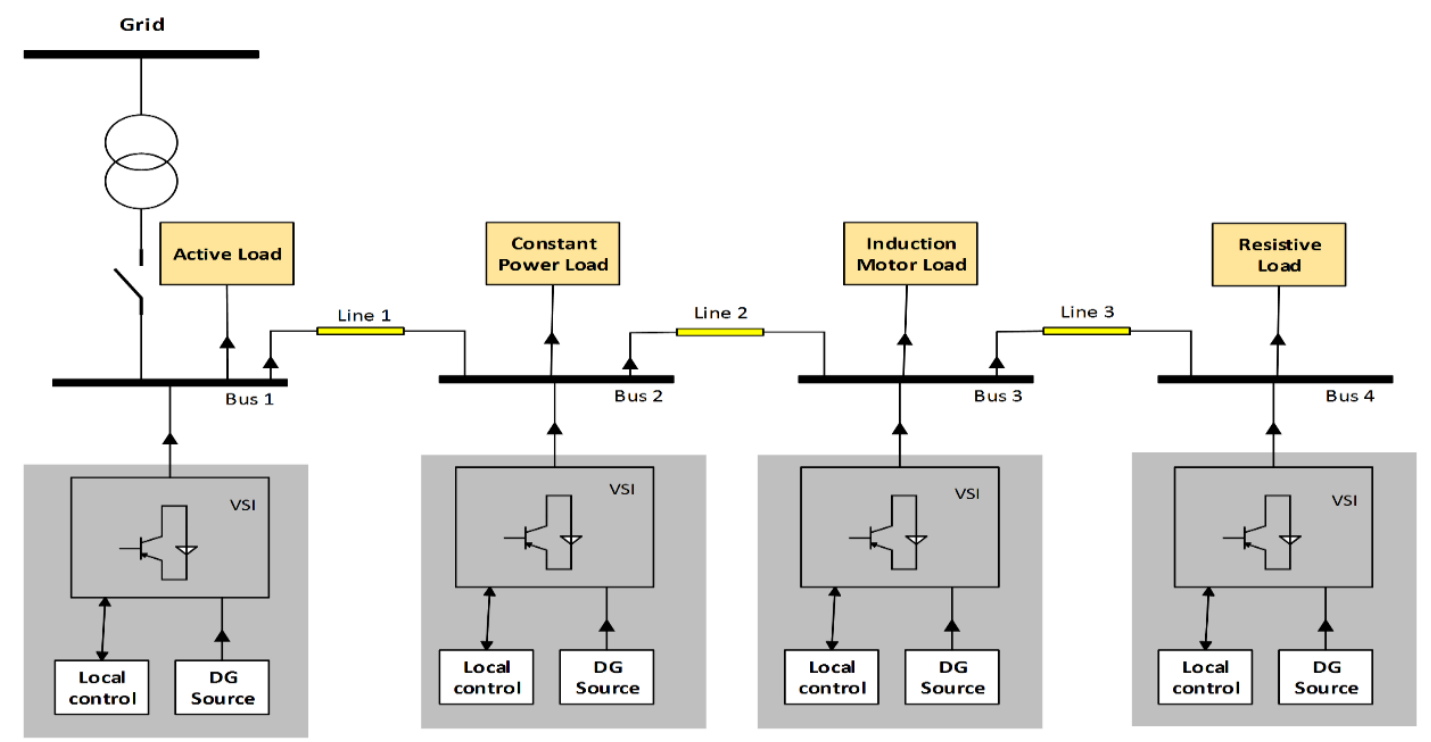

Figure 5. The configuration structure of the implemented islanded inverter-based microgrid including passive and active loads.

Table 1. Line parameters

\begin{tabular}{|c|c|c|}
\hline Line & Value & Unit \\
\hline 1 & $0.23+\mathrm{j} 0.11$ & $\Omega$ \\
\hline 2 & $0.35+\mathrm{j} 0.58$ & $\Omega$ \\
\hline 3 & $0.30+\mathrm{j} 0.47$ & $\Omega$ \\
\hline
\end{tabular}


Table 2. Islanded inverter-based distributed generations units parameters

\begin{tabular}{|c|c|c|}
\hline Parameter & Value & Unit \\
\hline $\mathrm{S}_{\text {IIDG1 }}$ & $(600+150 \mathrm{j})$ & $\mathrm{KVA}$ \\
\hline $\mathrm{S}_{\mathrm{IIDG} 2}$ & $(170+30 \mathrm{j})$ & $\mathrm{KVA}$ \\
\hline $\mathrm{S}_{\mathrm{IIDG} 3}$ & $(160+40 \mathrm{j})$ & $\mathrm{KVA}$ \\
\hline $\mathrm{S}_{\mathrm{IIDG} 4}$ & $(320+90 \mathrm{j})$ & $\mathrm{KVA}$ \\
\hline $\mathrm{L}_{\mathrm{f}}$ & 1.35 & $\mathrm{mH}$ \\
\hline $\mathrm{C}_{\mathrm{f}}$ & 5 & $\mu \mathrm{F}$ \\
\hline $\mathrm{R}_{\mathrm{f}}$ & 0.1 & $\Omega$ \\
\hline$\omega_{\mathrm{c}}$ & 31.41 & $\mathrm{rad} / \mathrm{s}$ \\
\hline $\mathrm{K}_{\mathrm{pv}}$ & 0.05 & - \\
\hline $\mathrm{K}_{\mathrm{iv}}$ & 390 & - \\
\hline $\mathrm{K}_{\mathrm{pi}}$ & 10.5 & - \\
\hline $\mathrm{K}_{\mathrm{ii}}$ & 16000 & - \\
\hline $\mathrm{F}$ & 0.75 & $\mathrm{mH}$ \\
\hline $\mathrm{R}_{\mathrm{c}}$ & 0.03 & \\
\hline $\mathrm{L}_{\mathrm{c}}$ & 0.5 & \\
\hline & & \\
\hline
\end{tabular}

Table 3. loads parameters.

\begin{tabular}{|c|c|c|c|}
\hline load & Parameter & Value & Unit \\
\hline \multirow{8}{*}{$\begin{array}{l}\text { Rectifier Interfaced Active Load } \\
\text { (RIAL) }\end{array}$} & $\mathrm{L}_{\mathrm{f}}$ & 2.3 & $\mathrm{mH}$ \\
\hline & $\mathrm{C}_{\mathrm{f}}$ & 8.8 & $\mu \mathrm{F}$ \\
\hline & $\mathrm{R}_{\mathrm{f}}$ & 0.1 & $\Omega$ \\
\hline & $\mathrm{f}_{\mathrm{sw}}$ & 10 & $\mathrm{kHz}$ \\
\hline & $\omega_{\mathrm{c}}$ & 31.41 & $\mathrm{rad} / \mathrm{s}$ \\
\hline & $\mathrm{P}_{\mathrm{RIAL}}$ & 25 & $\mathrm{~kW}$ \\
\hline & $\mathrm{R}_{\mathrm{RIAL}}$ & 6.347 & $\Omega$ \\
\hline & $\mathrm{V}_{\mathrm{DC}}$ & 700 & $\mathrm{~V}$ \\
\hline \multirow{4}{*}{ nduction Motor (IM) } & $\mathrm{P}_{\mathrm{IM}}$ & 10 & $\mathrm{hp}$ \\
\hline & $\mathrm{v}$ & 400 & $\mathrm{~V}$ \\
\hline & $\mathrm{P}$ & 4 & - \\
\hline & $\mathrm{T}_{\mathrm{L}}$ & 47.75 & N.m \\
\hline \multirow{3}{*}{$\begin{array}{l}\text { Constant Power Load } \\
\text { (CPL) }\end{array}$} & $\mathrm{P}_{\mathrm{CPL}}$ & 12 & $\mathrm{kVA}$ \\
\hline & $\mathrm{R}_{\mathrm{CPL}}$ & 13.224 & $\Omega /$ phase \\
\hline & $\cos \alpha$ & 0.85 & - \\
\hline \multirow{2}{*}{$\begin{array}{l}\text { Resistive Load } \\
\text { (RL) }\end{array}$} & $\mathrm{P}_{\mathrm{R}}$ & 25 & $\mathrm{~kW}$ \\
\hline & $\mathrm{R}_{\mathrm{R}}$ & 6.347 & $\Omega /$ phase \\
\hline
\end{tabular}




\subsection{Normal conditions}

In Figures 6-8, the active power, reactive power and frequency corresponding to the four islanded inverterbased distributed generations are illustrated, respectively. These figures have been carried out for verification of the nonlinear model of studied islanded-inverter-based microgrid system using the proposed generalized modelling approach. The time-domain simulation results have been obtained by solving a nonlinear differential-algebraic system of equations using numerical integration methods.

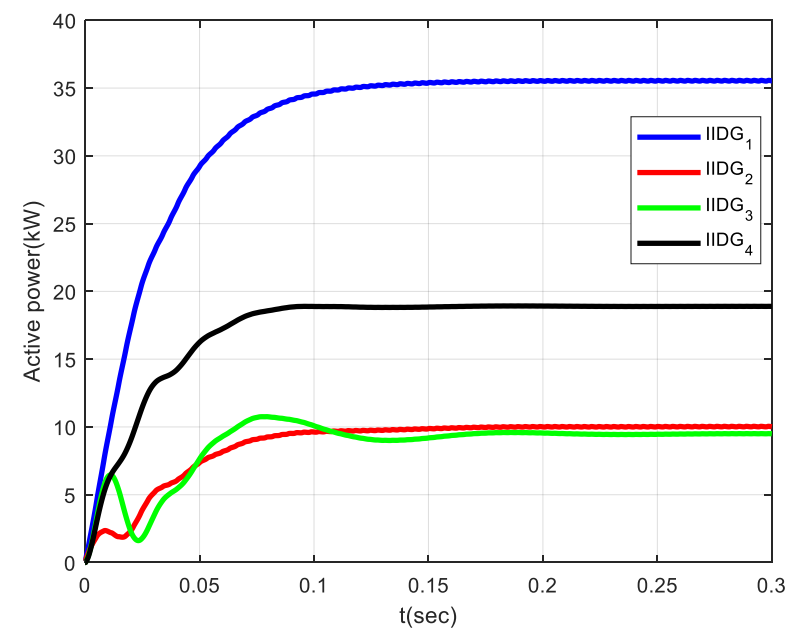

Figure 6. The response of active power outputs of islanded inverter-based distributed generation units.

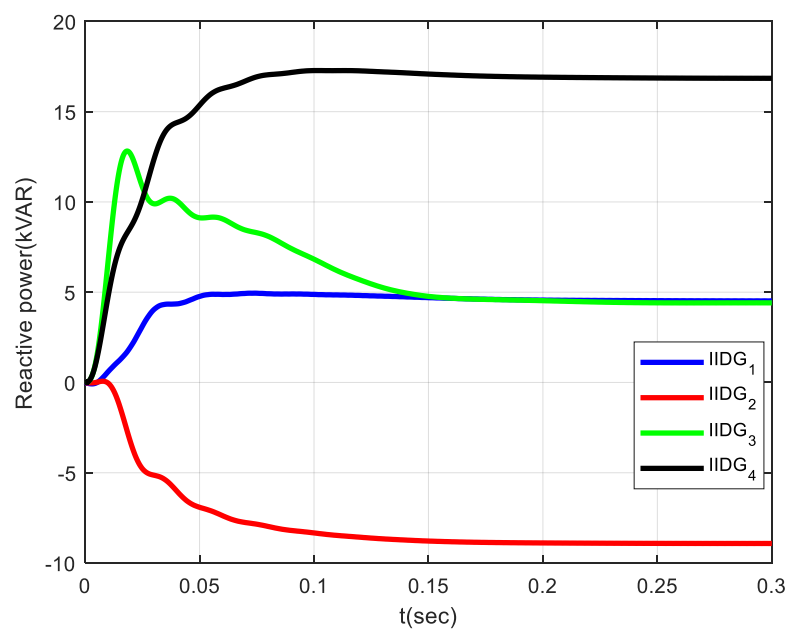

Figure 7. The response of reactive power outputs of islanded inverter-based distributed generation units. 


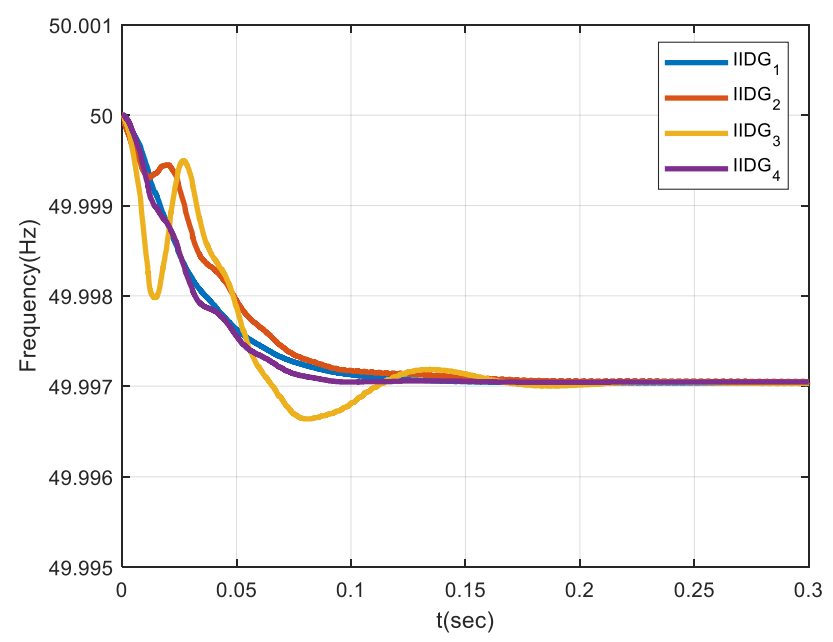

Figure 8. The response of frequency of islanded inverter-based distributed generation units.

According to Figures 6-8, it can be said that the active capacities produced by the IIDG units vary for each unit, because the nominal power of them considered unequal. This confirms that the division of active power between units is proportional to their nominal power.

According to Figure 7, it can be said that the reactive power produced by each IIDG unit is proportional to its nominal power, because of existence the high resistance line in a low or medium voltage microgrid leads to a current. It can also be seen that the reactive power response of the second IIDG is negative because it is connected to a constant power load. Also, the induction motor load in bus 3 increases the transients in response to reactive power. This statement proves the negative effect of the impedance increasing due to constant power load and the electromechanical oscillations caused by the induction motor dynamic load. The electromagnetic torque related to the induction motor dynamic load is shown in Figure 9. This figure shows the dynamic response to the electromagnetic torque of the induction motor, it can be said to operate at nominal load torque. Based on this figure, it is illustrating that in the transient state of the induction motor as a load connected to IIDG3 has a high electromagnetic torque that is five times the nominal value.

After passing the transient state, the electromagnetic torque reaches $50 \mathrm{Nm}$ approximately. Unlike other papers that dealing with the dynamic modelling of microgrid (Bani-Ahmed, Rashidi, \& Nasiri, 2019; Bassey, Butler-Purry, \& Chen, 2019; Bracco \& Delfino, 2017; Juneja, Nagar, \& Mohanty, 2019; Macana, Mojica-Nava, Pota, Guerrero, \& Vasquez, 2019; Magdy, Mohamed, Shabib, Elbaset, \& Mitani, 2018; Shuai, Peng, Guerrero, Li, \& Shen, 2018), this paper explores the dynamic response of induction motors, completely.

In Figures 10 and 11, the dynamic responses of the voltage and current of the three-phase output for the third IIDG unit are shown, which supplies an induction motor. Induction motors are nonlinear higher-order dynamic systems of considerable complexity. They are well amenable to a formal mathematical analysis. It has proved more difficult to comprehend and penetrate in the principles of their operation under transient conditions. These complex dynamics of the induction motor cause severe oscillations in its current response. 


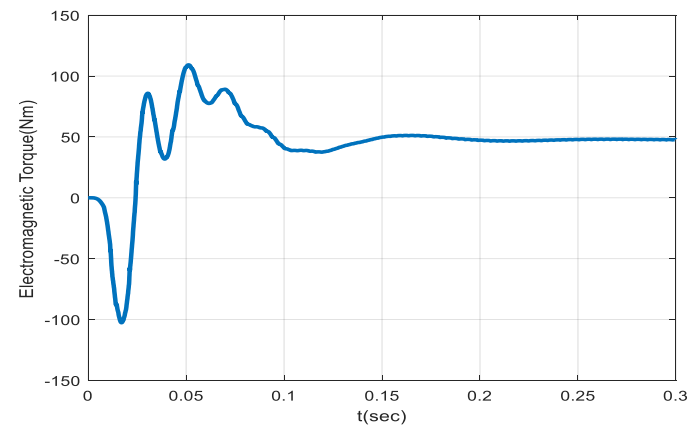

Figure 9. The response of the electromagnetic torque of induction motor.

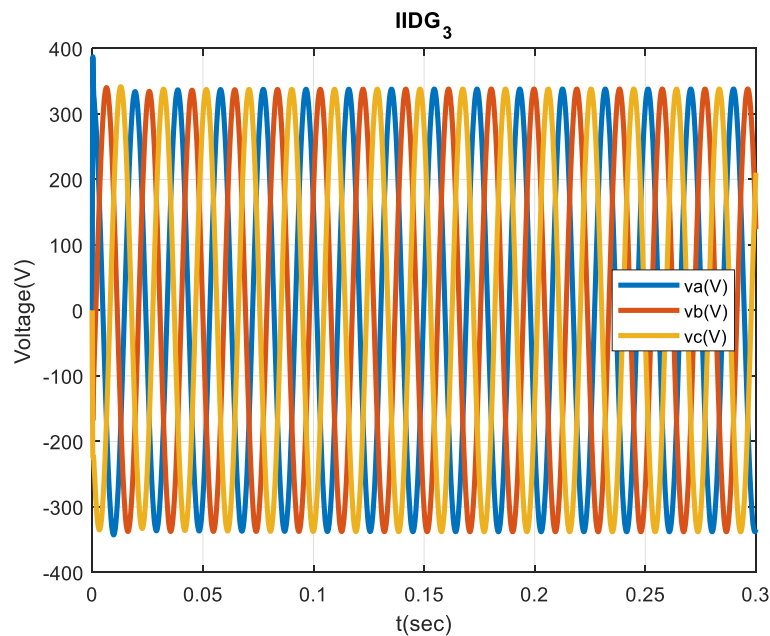

Figure 10. The voltage response of the IIDG 3.

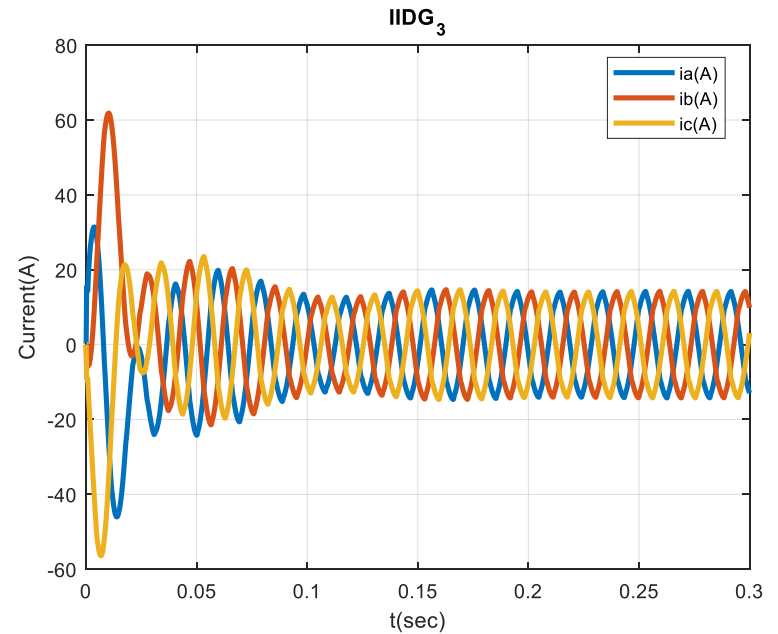

Figure 11. The current response of the IIDG 3. 


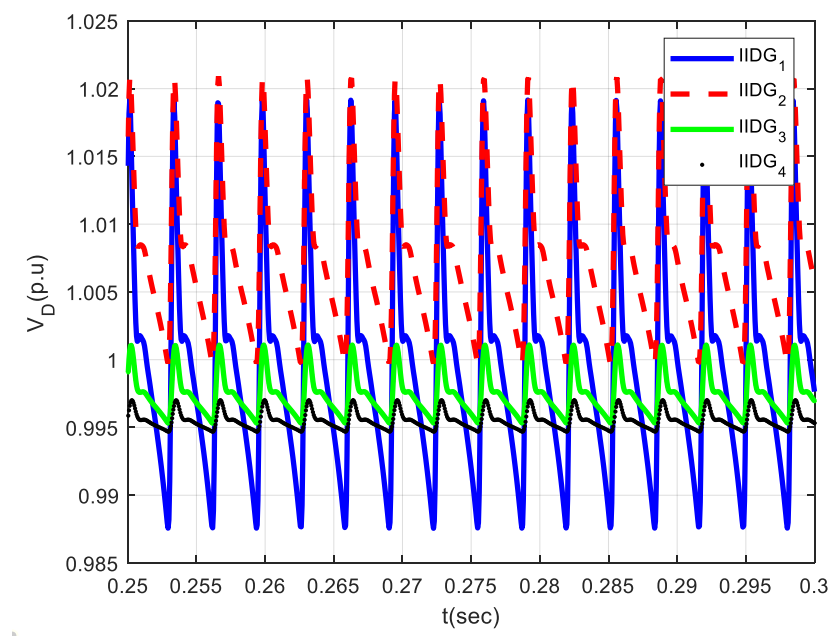

Figure 12. The dynamic response of the d-axis voltage at IIDG buses.

Due to the three-phase current response of the third IIDG unit, it is observed that sudden transient has occurred because of the nonlinear dynamics associated with the induction motor dynamic load connected to this IIDG unit. In Figure 12, the dynamic response of the D-axis voltage for the 4 connected buses to the IIDG units are shown.

\subsection{Disturbances condition}

The performance of the proposed modelling mechanism during disturbance is investigated. The disturbance applied in this section is increasing the rated output voltage over a given time interval. This component increasing from $V_{n}$ to $1.1 V_{n}$ in $[0.45,0.65]$. According to Figures 13 and 14, it is observed that in the presence of voltage sag, the active power of IIDG1, IIDG3 and IIDG4 units are changed, but power active of IIDG2 unit, which supplies the CPL is constant. Also, the reactive power of IIDG2, IIDG3 and IIDG4 units are change but IIDG1 unit, that connected to the RIAL is constant. Furthermore, the Figures 15 and 16 illustrated frequency of IIDGs and electromagnetic torque of induction motor at disturbance condition.

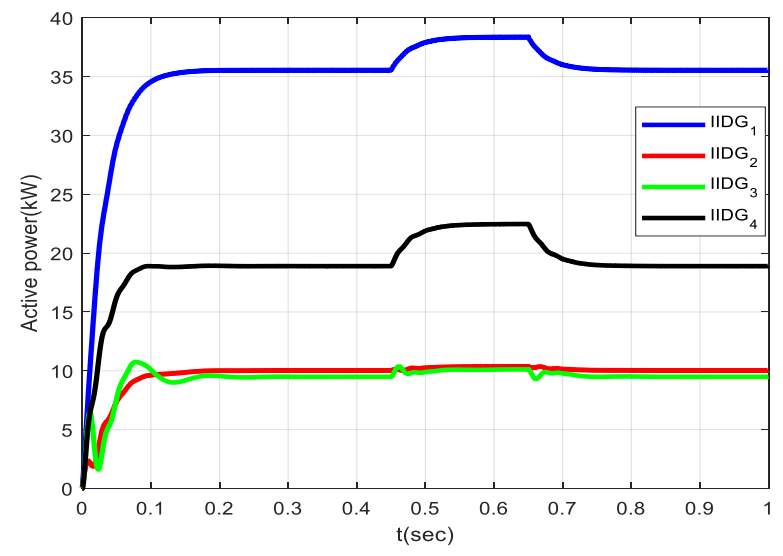

Figure 13. The response of active power outputs of islanded inverter-based DG units at disturbance condition. 


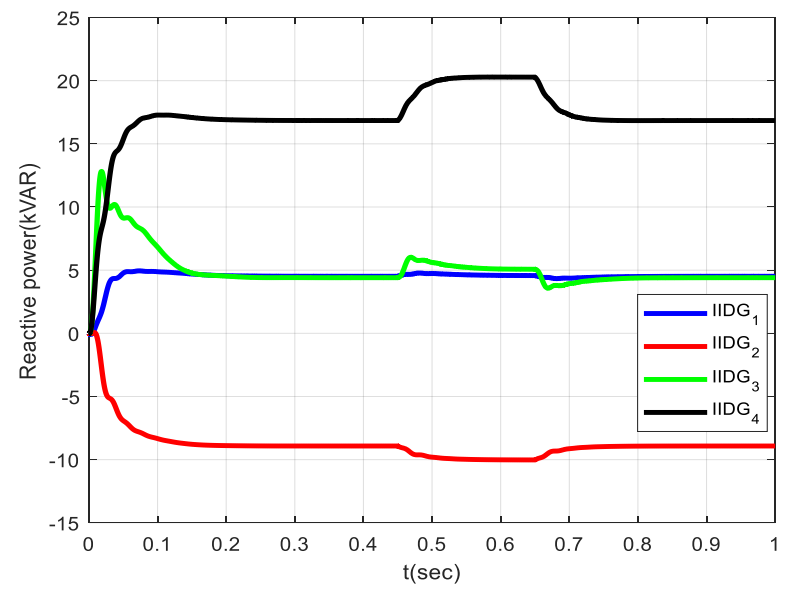

Figure 14. The response of reactive power outputs of islanded inverter-based DG units at disturbance condition.

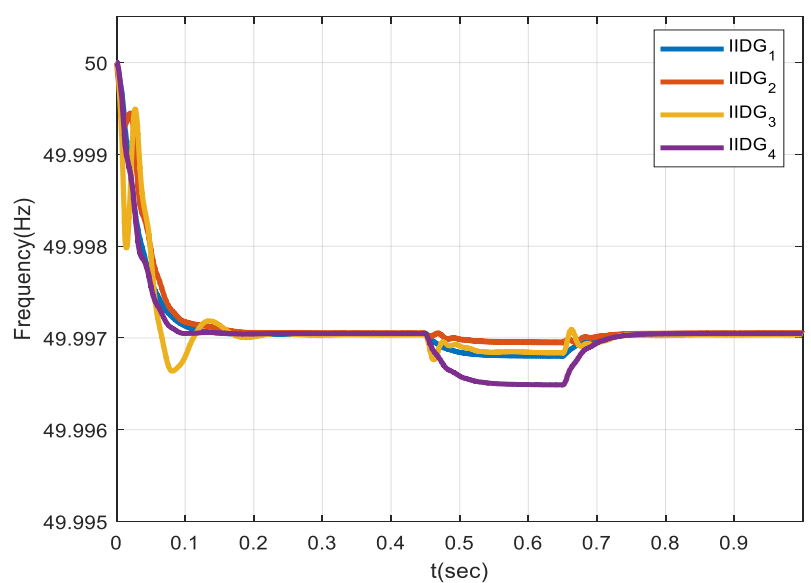

Figure 15. The response of frequency of islanded inverter-based DG units at disturbance condition.

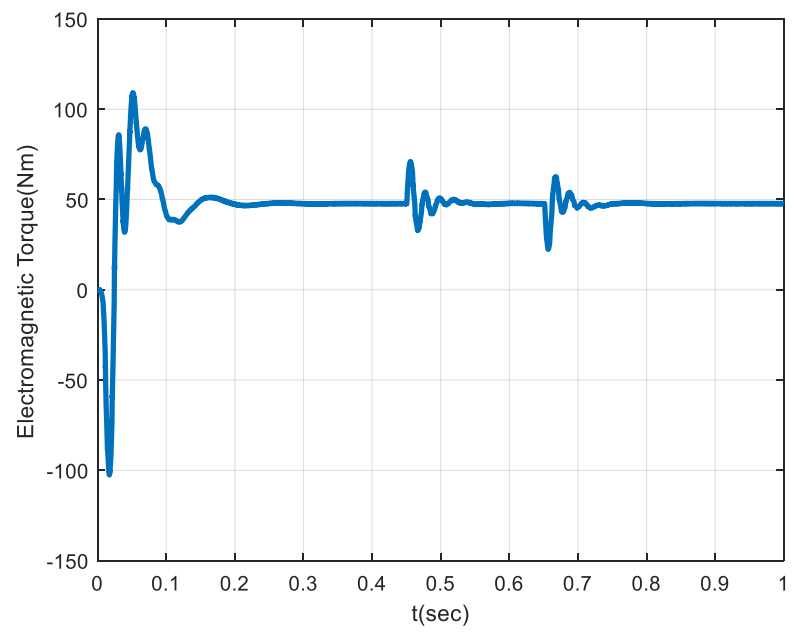

Figure 16. The response of the electromagnetic torque of induction motor at disturbance condition. 
It is shown in Figure 15 that the frequency of IIDG1, IIDG3 and IIDG4 units are changed in presence of voltage sag over the specified time interval and only the frequency of IIDG2 unit is constant. In addition to, disturbance occurrence causes oscillations in torque of induction motor that connected to the IIDG3 unit.

\subsection{Comparison between Mfile and Simulink results}

In this section, in order to validate the results of propsed modelling approach, these results are compared with the responses of a detailed simulated system by Raju method (Raju \& Jain, 2019) during disturbance, which are shown in Figures 17-20. The disturbance applied in this section is increasing the rated output voltage over a given time interval. This component increasing from $V_{n}$ to $1.1 V_{n}$ in $[0.45,0.65]$. In Figures, the reactive power of IIDG1, active power of IIDG2, frequency of IIDG3, and electromagnetic torque are provided. It is clear that the response from both methods are very similar.

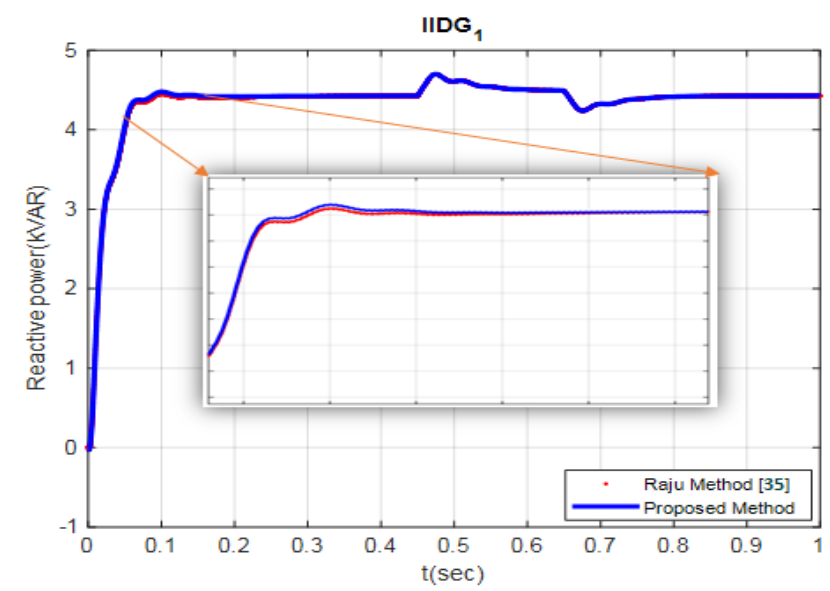

Figure 17. The reactive power of IIDG1 based on proposed method and Raju method (Raju \& Jain, 2019).

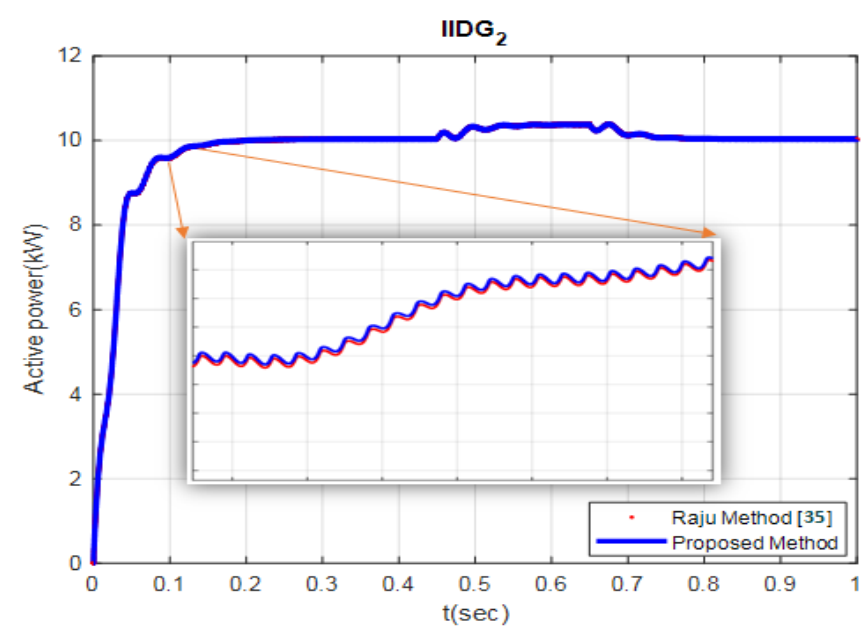

Figure 18. The active power of IIDG2 based on proposed method and Raju method (Raju \& Jain, 2019). 


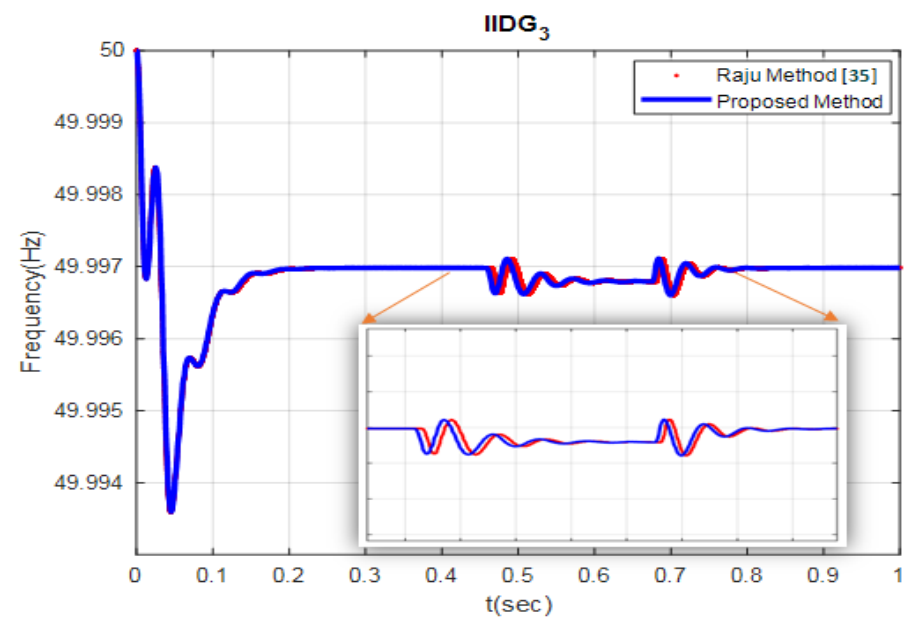

Figure 19. The frequency of IIDG3 based on proposed method and Raju method (Raju \& Jain, 2019).

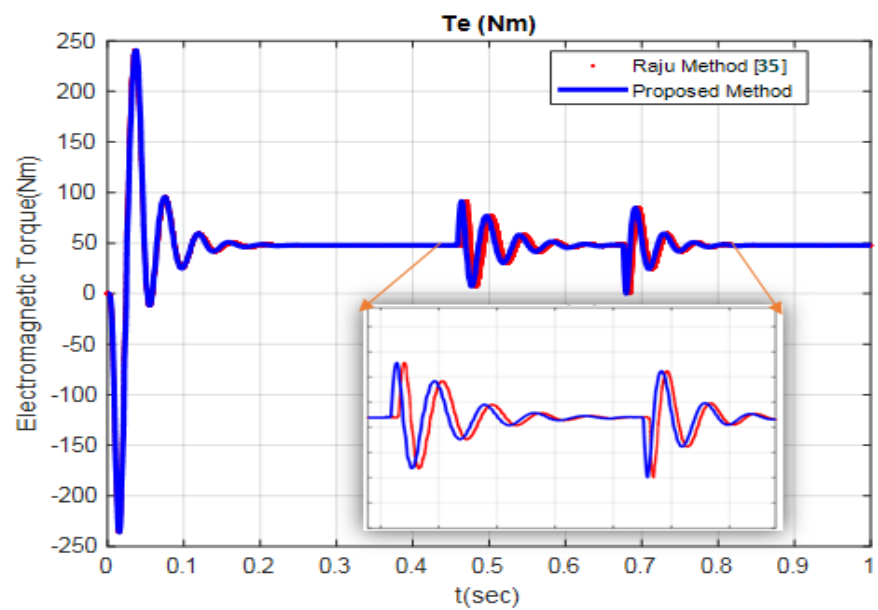

Figure 20. The induction motor electromagnetic torque based on proposed method and Raju method (Raju \& Jain,

2019).

\section{CONCLUSION}

The dynamic behavior of islanded inverter-based microgrids became more complex with the increasing of distributed generation penetration. Therefore, the stability studies of these microgrids in transient state have a great importance. In this paper, a comprehensive model of islanded inverter-based microgrids with static and dynamic loads is presented. The structure of this model has been divided into three sub modules that included generation sub module, network sub module and load sub module. All of them developed in a similar dq reference frame. One of the benefits of this modelling approach is to consider the detailed dynamics of the islanded inverter-based microgrids, which including low and high-frequency dynamics of islanded inverter-based distributed generation units, dynamics of RL line configuration between islanded inverter-based distributed generation units, dynamics of passive, active and dynamic load and interaction between the control loops of islanded inverter-based distributed generation units and loads. The effectiveness of the proposed non-linear comprehensive model for islanded inverter-based microgrids is illustrated using time-domain simulation. Based on the results, it is evident that the proposed model has a 
high capability for transient state stability analysis and proper design of islanded inverter-based microgrids control structures that ensures its safe and reliable operation.

\section{REFERENCES}

Alam, M. M., Moreira, C., Islam, M. R., \& Mehedi, I. M. (2019). Continuous Power Flow Analysis for MicroGeneration Integration at Low Voltage Grid.

Bani-Ahmed, A., Rashidi, M., \& Nasiri, A. (2019). Decentralised resilient autonomous control architecture for dynamic microgrids. IET Generation, Transmission \& Distribution, 13(11), 2182-2189.

Bassey, O., Butler-Purry, K. L., \& Chen, B. (2019). Dynamic modeling of sequential service restoration in islanded single master microgrids. IEEE Transactions on Power Systems, 35(1), 202-214.

Belvedere, B., Bianchi, M., Borghetti, A., Nucci, C. A., Paolone, M., \& Peretto, A. (2012). A microcontroller-based power management system for standalone microgrids with hybrid power supply. IEEE Transactions on Sustainable Energy, 3(3), 422-431.

Bevrani, H., François, B., \& Ise, T. (2017). Microgrid dynamics and control: John Wiley \& Sons.

Bottrell, N., Prodanovic, M., \& Green, T. C. (2013). Dynamic stability of a microgrid with an active load. IEEE Transactions on Power Electronics, 28(11), 5107-5119.

Bracco, S., \& Delfino, F. (2017). A mathematical model for the dynamic simulation of low size cogeneration gas turbines within smart microgrids. Energy, 119, 710-723.

Du, Y., Lu, X., Wang, J., \& Lukic, S. (2018). Distributed secondary control strategy for microgrid operation with dynamic boundaries. IEEE Transactions on Smart Grid, 10(5), 5269-5282.

Ferraro, P., Crisostomi, E., Shorten, R., \& Milano, F. (2018). Stochastic frequency control of grid-connected microgrids. IEEE Transactions on Power Systems, 33(5), 5704-5713.

Hassan, M. A. (2018). Dynamic stability of an autonomous microgrid considering active load impact with a new dedicated synchronization scheme. IEEE Transactions on Power Systems, 33(5), 4994-5005.

Hatziargyriou, N. D., Kanellos, F., Kariniotakis, G., Le Pivert, X., Jenkins, N., Jayawarna, N., . . Oyarzabal, J. (2004). Modelling of micro-sources for security studies.

Ishchenko, A. (2008). Dynamics and stability of distribution networks with dispersed generation. Technische Universiteit Eindhoven.

Jafari, H., Mahmoudi, M., Fatehi, A., Naderi, M. H., \& Kaya, E. (2018). Improved power sharing with a back-to-back converter and state-feedback control in a utility-connected microgrid.

Juneja, M., Nagar, S. K., \& Mohanty, S. R. (2019). ABC based reduced order modelling of microgrid in grid-tied mode. Control Engineering Practice, 84, 337-348.

Kanellos, F. D., Tsouchnikas, A. I., \& Hatziargyriou, N. D. (2005). Micro-grid simulation during grid-connected and islanded modes of operation.

Macana, C. A., Mojica-Nava, E., Pota, H. R., Guerrero, J. M., \& Vasquez, J. C. (2019). A novel compact dq-reference frame model for inverter-based microgrids. Electronics, 8(11), 1326.

Magdy, G., Mohamed, E. A., Shabib, G., Elbaset, A. A., \& Mitani, Y. (2018). Microgrid dynamic security considering high penetration of renewable energy. Protection and Control of Modern Power Systems, 3(1), 1-11. 
Nguyen, C.-K., Nguyen, T.-T., Yoo, H.-J., \& Kim, H.-M. (2018). Improving transient response of power converter in a stand-alone microgrid using virtual synchronous generator. Energies, 11(1), 27.

Ortega, A., \& Milano, F. (2015). Generalized model of VSC-based energy storage systems for transient stability analysis. IEEE transactions on Power Systems, 31(5), 3369-3380.

Ortega, A., \& Milano, F. (2016). Modeling, simulation, and comparison of control techniques for energy storage systems. IEEE transactions on Power Systems, 32(3), 2445-2454.

Ou, T.-C., \& Hong, C.-M. (2014). Dynamic operation and control of microgrid hybrid power systems. Energy, 66, 314-323.

Pérez-Ibacache, R., Silva, C. A., \& Yazdani, A. (2018). Linear state-feedback primary control for enhanced dynamic response of ac microgrids. IEEE Transactions on Smart Grid, 10(3), 3149-3161.

Pérez, M., Ortega, R., \& Espinoza, J. R. (2004). Passivity-based PI control of switched power converters. IEEE Transactions on Control Systems Technology, 12(6), 881-890.

Pogaku, N., Prodanovic, M., \& Green, T. C. (2007). Modeling, analysis and testing of autonomous operation of an inverter-based microgrid. IEEE Transactions on power electronics, 22(2), 613-625.

Raju, P., \& Jain, T. (2019). Development and validation of a generalized modeling approach for islanded inverterbased microgrids with static and dynamic loads. International Journal of Electrical Power \& Energy Systems, 108, 177-190.

Rocabert, J., Luna, A., Blaabjerg, F., \& Rodriguez, P. (2012). Control of power converters in AC microgrids. IEEE transactions on power electronics, 27(11), 4734-4749.

Sarkar, S. K., Badal, F. R., \& Das, S. K. (2018). A comparative study of high performance robust pid controller for grid voltage control of islanded microgrid. International Journal of Dynamics and Control, 6(3), 1207-1217.

Serra, F. M., De Angelo, C. H., \& Forchetti, D. G. (2014). Interconnection and damping assignment control of a threephase front end converter. International Journal of Electrical Power \& Energy Systems, 60, 317-324.

Shuai, Z., Peng, Y., Guerrero, J. M., Li, Y., \& Shen, Z. J. (2018). Transient response analysis of inverter-based microgrids under unbalanced conditions using a dynamic phasor model. IEEE Transactions on Industrial Electronics, 66(4), 2868-2879.

Smith, N., \& McCann, R. (2017). Energy shaping control of a back-to-back converter for microgrid applications.

Soni, N., Doolla, S., \& Chandorkar, M. C. (2017). Analysis of frequency transients in isolated microgrids. IEEE Transactions on Industry Applications, 53(6), 5940-5951.

Stavrakakis, G. S., \& Kariniotakis, G. N. (1995). A general simulation algorithm for the accurate assessment of isolated diesel-wind turbines systems interaction. I. A general multimachine power system model. IEEE transactions on Energy Conversion, 10(3), 577-583.

Wai, R.-J., \& Wang, W.-H. (2008). Grid-connected photovoltaic generation system. IEEE Transactions on Circuits and Systems I: Regular Papers, 55(3), 953-964.

Wang, X., Guerrero, J. M., Blaabjerg, F., \& Chen, Z. (2012). A review of power electronics based microgrids. International Journal of Power Electronics, 12(1), 181-192.

Zhu, Y., \& Tomsovic, K. (2002). Development of models for analyzing the load-following performance of microturbines and fuel cells. Electric Power Systems Research, 62(1), 1-11. 